\title{
Retroperitoneal Paraganglioma Mimicking Lymph Node Metastasis in an Endometrial Cancer Patient: Case Report
}

\author{
Bir Endometriyum Kanseri Hastasinda \\ Lenf Nodu Metastazını Taklit Eden \\ Retroperitoneal Paragangliom
}

Selen DOĞAN, ${ }^{a, b}$
Tayfun TOPTAŞ, ${ }^{a, b}$
Gülgün ERDOĞAN, ${ }^{c}$
Güzide Ayşe OCAK, ${ }^{c}$
Tayup ŞiMŞEK,
Binnur KARAYALÇIN ${ }^{a}$

Departments of

aObstetrics and Gynecology,

bDivision of Gynecologic Oncologic Surgery, 'Pathology,

dNuclear Medicine,

Akdeniz University Faculty of Medicine,

Antalya

Geliş Tarihi/Received: 02.04 .2014

Kabul Tarihi/Accepted: 24.06.2014

Yazışma Adresi/Correspondence:

Selen DOĞAN

Akdeniz University Faculty of Medicine, Department of Obstetrics and Gynecology, Division of Gynecologic Oncologic Surgery, Antalya,

TÜRKIYE/TURKEY

selendogan@akdeniz.edu.tr

doi: 10.5336/gynobstet.2014-40079

Copyright $(02015$ by Türkiye Klinikleri

\begin{abstract}
Paraganglioma is the term used for tumoral development of chromaffin cells which are embrionically derived from neuroectoderm. They are mostly functional when they located abdominally and hypertension, headaches, perspiration and palpitation are the most commonly encountered implications of the disease. We presenting here the first case of an asymptomatic paraganglioma arising in an endometrial cancer patient and mimicking paraaortic lymphatic involvement of advanced stage endometrial cancer.
\end{abstract}

Key Words: Endometrial neoplasms; carcinoma, neuroendocrine; paraganglioma

ÖZET Paragangliom terimi, nöroektodermden köken alan kromaffin hücrelerinden gelişen tümörler için kullanılmaktadır. Bu tümörler abdominal bölgede yerleştiğinde sıklıkla fonksiyoneldir ve hipertansiyon, baş ağrısı, çarpıntı terleme en sık rastlanan yansımalarıdır. Biz burada literatürde ilk olan, bir endometriyum kanseri hastasında, paraaortik lenf nodu tutulumlu ileri evre hastalığ taklit eden asemptomatik paragangliom olgusunu sunmaktayız.

Anahtar Kelimeler: Endometrial tümörler; karsinom, nöroendokrin; paragangliom

Turkiye Klinikleri J Gynecol Obst 2015;25(3):209-12

$\mathrm{P}$ araganglioma is the term used for tumoral development of chromaffin cells which are embrionically derived from neuroectoderm. If the origin is adrenal medulla the term pheochromositoma is preferred instead of paraganglioma. ${ }^{1}$ Function of chromaffin cells in paraganglioma is similar to adrenal medulla and they secrete and store cathecolamines in response to neuronal signals. ${ }^{2}$ Paraganglioma can be located at carotid body, glomus jugulare, mediastinal, and abdominal region. They are mostly functional when they located abdominally and hypertension, headaches, perspiration and palpitation are the most commonly encountered implications of the disease. ${ }^{3}$ Unexpected finding on pathologic examination is the most common presentation of nonfunctional tumors. ${ }^{3}$

Two cases of retroperitoneal paraganglioma in ovarian and cervical cancer patients were reported so far among genital cancers. ${ }^{4,5} \mathrm{We}$ presenting here the first case of an asymptomatic paraganglioma arising in an endometrium cancer patient and mimicking lymphatic involvement of advanced stage endometrium cancer. 


\section{CASE REPORT}

A 49-year-old G8 P5 A3 perimenopausal woman referred to our tertiary center with final pathology of endometrioid type endometrium cancer, after she underwent total abdominal hysterectomy and bilateral salpingoopherectomy for abnormal vaginal bleeding. Pathologic examination revealed tumor size of $3.5 \mathrm{~cm}$, superficial myometrial invasion and grade 1 histologic architecture. Her medical history was unremarkable. Her preoperative blood pressure was $110 / 60 \mathrm{mmHg}$ and pulse rate was $90 / \mathrm{min}$. Preoperative PET-CT evaluation of whole body exposed hypermetabolic lymph node with 4.86 SUVmax level suggesting metastasis at aortakaval region (Figure 1). Another pathologic hypermetabolic FDG uptake suggesting distant metastasis was not observed. Patient underwent pelvic and paraaortic lymph node dissection with a view to complete surgery. During paraaortic lymph node dissection a $5 \mathrm{~cm}$ of highly vascular lymph node was detected at the right low paraaortic region just above aortic bifurcation. Aberrant small vascular structures were observed around the lesion which produce severe haemorhage during dissection. Alterations on vital signs were not observed during manipulation or throughout surgery. Mass was completely excised without residual disease. Frozen section examination revealed nonspesific malign tumoral lesion. Abdominal and pelvic peritoneal surfaces, liver, spleen, stomach, and omentum were normal macroscopically. Macroscopic pathologic examination revealed well circumscribed, $5 \mathrm{~cm}$ solid mass with smooth surface, regular margin and thin capsule. On microscopic analysis nuclear pleomorphism, hypercellularity with hyperchromatic nucleus and clear eozinophylic granular cytoplasm with nest like clusters and diffuse growing pattern were observed. Capsule penetration was not reported (Figure 2). Also diffuse positive cytoplasmic immunostaining for chromogranin A and synaptophysin, and s-100 positivity in sustentacular cells were noted (Figure 3). Mitosis and necrosis were not detected. Finally pheochromacitoma arising in an ectopic adrenal tissue rest namely 'paraganglioma' was diagnosed. Malignant cells were not observed in cytologic examination of peritoneal washing fluids. Finall stage1a endometrial cancer without lymphatic involvement was diagnosed according to the FIGO 2009 classification. Due to potential malign behavior of these type of tumor systemic evaluation with radiologic imaging, biochemical analysis and pathologic investigation of surrenal lesion were scheduled. But patient was lost to follow up.

\section{DISCUSSION}

Functionality is the major issue affecting prognosis and important for diagnosis in patients with paraganglioma. Preoperative diagnosis in paraganglioma/pheochromasitoma is possible with

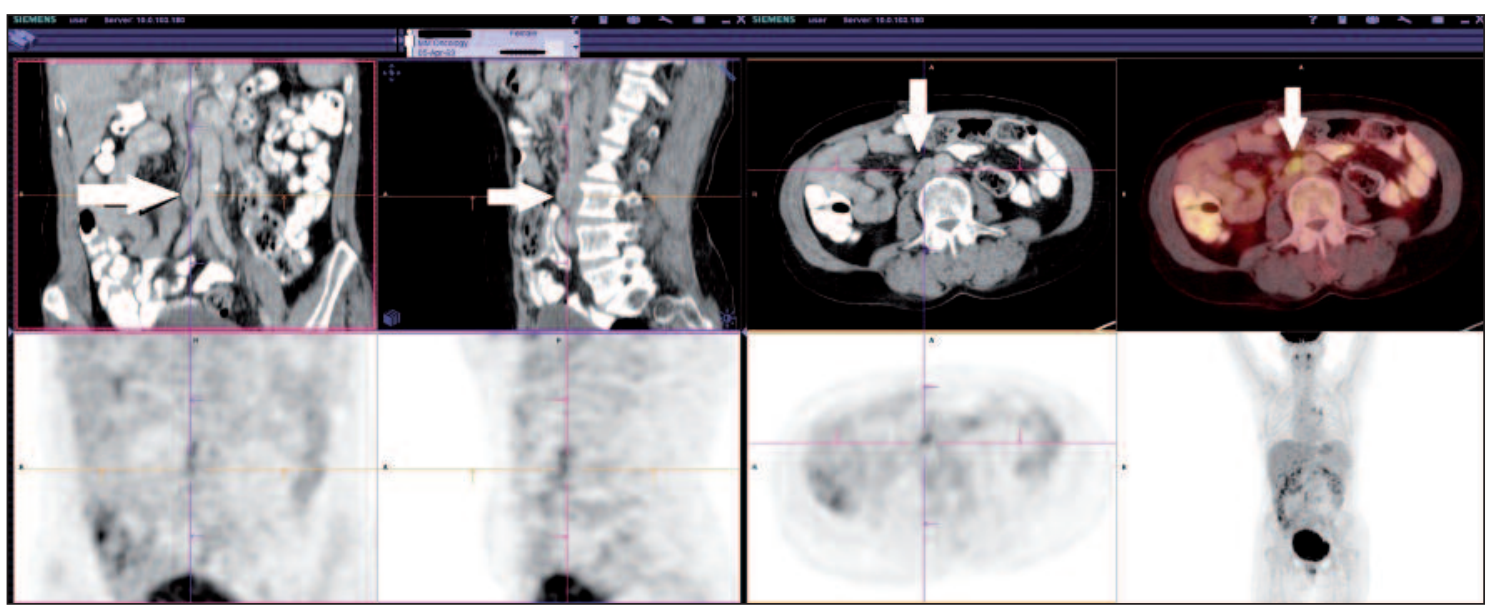

FIGURE 1: Preoperative PET/CT images of nonfunctional retroperitoneal paraganglioma, white arrow shows the paraganglioma and its metabolic activity in coronal, sagittal and horizontal plane. 


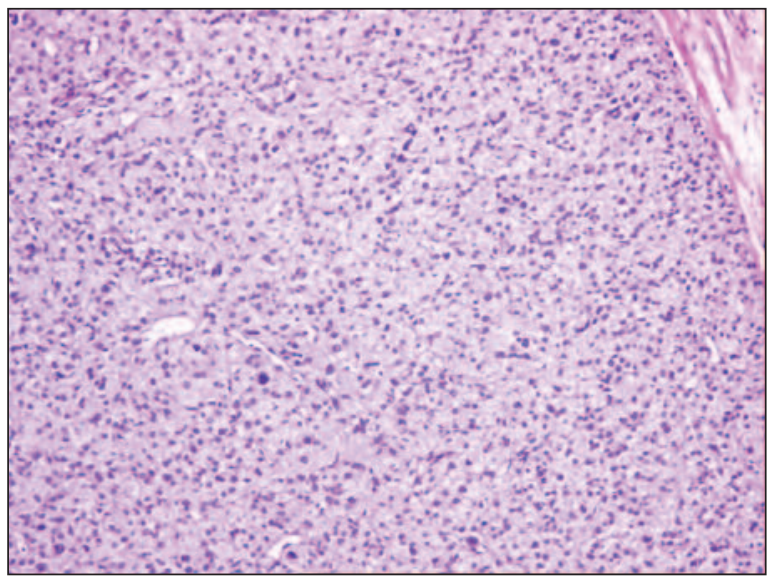

FIGURE 2: Zelballen pattern, Haemotoxylen-eozin stain (×100 magnification).

cathecolaminergic clinical symptoms and biochemical analysis, and require to use pharmacologic prophylaxis to prevent acute effects of released cathecolamines during surgery. Asymptomatic retroperitoneal paraganglioma is a very rare entity. So far only a few cases were reported. ${ }^{6}$ Our case is the first case of a paraaortic paraganglioma detected during paraaortic lymphadenectomy in an endometrium cancer patient. In our case radiologic appearance leads to suspicion of advanced stage endometrium cancer with lymphatic involvement, however the disease is low risk early stage in fact. Differential diagnosis of lymphatic involvement in intraabdominal region categorized as malignant diseases and reactive processes. Malignant lymphadenomegaly can be caused by metastasis from tumors of intraabdominal solid organs or hematologic malignancies. Reactive lymphadenomegaly can be caused by bacterial, viral infections and tuberculosis or inflammatory diseases such as Crohn disease and pancreatitis. Due to lack of clinical symptoms, suspicion was not beyond lymphatic involvement of endometrium cancer in this case and biochemical analysis for neuroendocrine tumors was not performed preoperatively. Absence of clinical symptoms preoperatively and hemodynamic instability during dissection of the tumor from aorta supports the diagnosis of nonfunctionality in our case. Anyway, despite biochemically silent tumor in preoperatively diagnosed patients, surgeons must be aware of transient rising of blood pressure during operation. ${ }^{3,7}$ In the case of nonfunctional tumor, preoperative diagnosis is difficult and mostly depends on growing mass effect. Close relationship with aorta on computed tomography (CT) images helps to differantiate nonfunctional paraganglioma from other retroperitoneal tumors such as neurofibroma, mesodermal tumors and liposarcoma. But other hallmarks on CT overlaps with other tumors and nondiagnostic for nonfunctional paraganglioma. ${ }^{8}$ This explains why nonfunctional paragangliomas are mostly inciden-

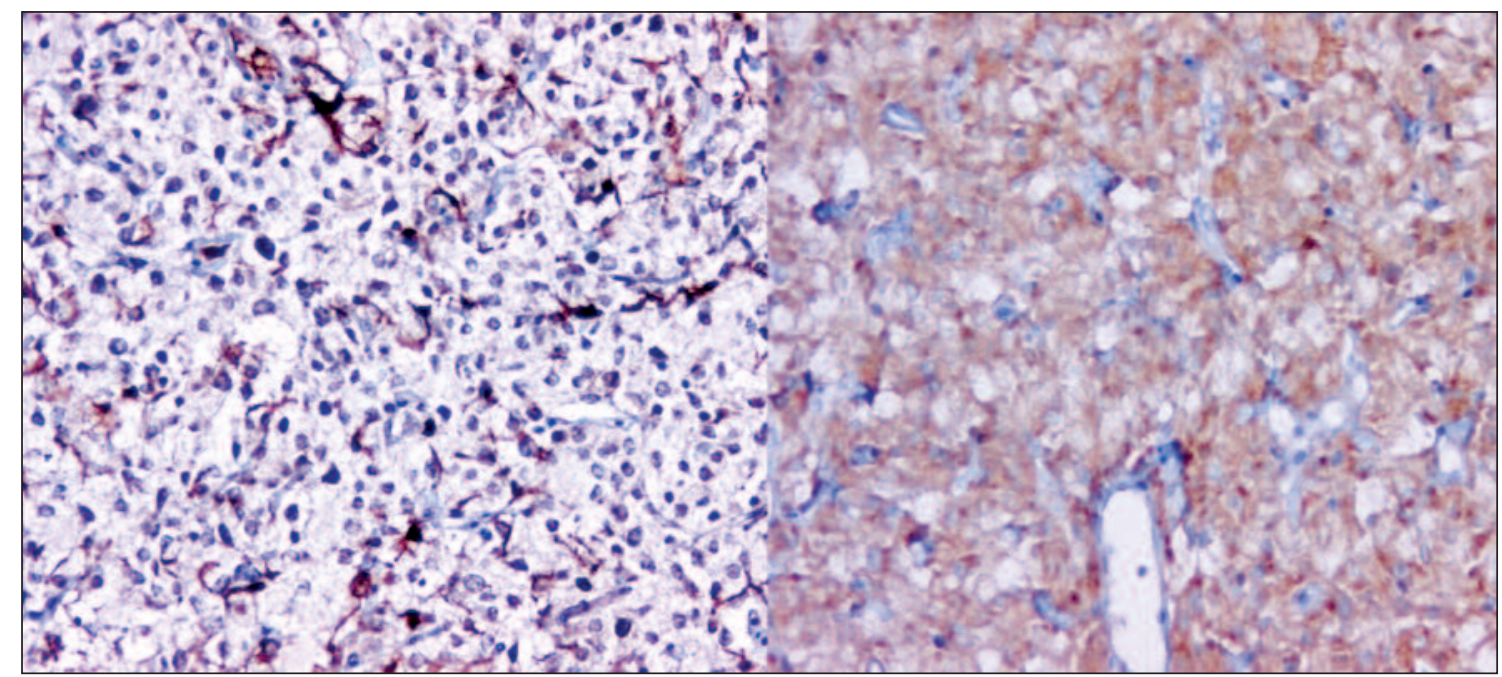

FIGURE 3: S-100 and Synaptophysin positivity in sustentacular cells (×200 magnification) 
tal findings on final pathologic reports. Regarding PET-CT evaluation, functional status of the tumor could not be predicted by FDG uptake level, however malignant lesions had higher FDG uptake than benign lesions. ${ }^{9}$

Positive family history of paraganglioma related syndromes (Von hippel Lindau, MEN2b, Familial paraganglioma [SDHB gene mutation]) is reported to be $12.5 \%$ in patients with paraganglioma. Clinicians must be aware of the components of these syndromes especially in case of multifocal tumor during follow up. ${ }^{10}$ Carney triad (Paraganglioma, Gastric leomyosarcoma, Pulmonary chondroma) as a nonfamilial association also can be observed. Recently adrenocortical tumor was described as fourth component of this association. $^{3,11}$

Histologically paraganglioma composed of type 1 chief/granular cells and type 2 supportive/ sustentacular cells. Characteristic Zelballen pattern of these cells and immunhystochemical staining helps to differantiate paraganglioma/pheochromositoma from other nonneuroendocrine tumors. ${ }^{2}$ When a paraganglioma was diognosed, risk of malign behavior is another important issue. Pheochromocytoma of the adrenal gland scaled score (PASS) criteria based on histomorphologic characteristics including necrosis, large nests, high cellularity, nuclear pleomorphism, hyperchromasia and local invasion was described in literature for discrimination of malign and benign pheochromositoma. ${ }^{12} \mathrm{How}^{-}$ ever they are only suggestive of malignancy and the only absolute sign of malignancy is distant metastasis. ${ }^{13}$

Regarding management, retroperitoneal located paragangliomas has higher risk of malign transformation than other sites, thus total excision and systemic evaluation are the basis of curative treatment. ${ }^{7}$ If surgery is not feasible and response to treatment with radionuclides unsatisfactory, chemotherapy is another succesful treatment modality in malign disease. ${ }^{13}$ After primary treatment, long term follow up recommended due to late recurrences even after years. ${ }^{3}$

In conclusion, retroperitoneal paraaortic surgery is well known and commonly used procedure by gynecologic oncologists. However neuroendocrine tumors of this area were rarely encountered. Due to their anatomic locations misdiagnosis as lymph node metastasis can occur. During paraaortic tumoral resection, these types of tumor should kept in mind and surgeons must be careful regarding intra and postoperative complications especially in case of functional tumor.

\section{REFERENCES}

1. DeLellis R, The International Agency for Research on Cancer. Pathology \& Genetics: Tumours of Endocrine Organs. $1^{\text {st }}$ ed. Geneva: World Health Organization; 2004.p.1-320.

2. Wasserman PG, Savargaonkar P. Paragangliomas: classification, pathology, and differential diagnosis. Otolaryngol Clin North Am 2001;34(5): 845-62, v-vi.

3. Erickson D, Kudva YC, Ebersold MJ, Thompson GB, Grant CS, van Heerden JA, et al. Benign paragangliomas: clinical presentation and treatment outcomes in 236 patients. J Clin Endocrinol Metab 2001;86(11):5210-6.

4. Chishima F, Tamura M, Nakazawa T, Sugitani M, Hirano D, Yoshikawa T, et al. Paraaortic paraganglioma arising in an ovarian carcinoma patient mimicking lymph node metastasis. J Obstet Gynaecol Res 2010;36(1):204-8.

5. Phillips JG, Orr JW Jr, Grizzle W, Hatch KD, Shingleton HM. An extra-adrenal pheochromocytoma mimicking lymph node metastasis from a cervical cancer. Gynecol Oncol 1982;13(3):416-22.
6. Uchiyama S, Ikenaga N, Haruyama Y, Nagaike K, Hotokezaka M, Kai M, et al, Asymptomatic extraadrenal paraganglioma masquerading as retroperitoneal sarcoma. Clin J Gastroenterol 2010;3(1):13-7.

7. Wen J, Li HZ, Ji ZG, Mao QZ, Shi BB, Yan WG. A decade of clinical experience with extra-adrenal paragangliomas of retroperitoneum: Report of 67 cases and a literature review. Urol Ann 2010;2(1): $12-6$.

8. Hayes WS, Davidson AJ, Grimley PM, Hartman DS. Extraadrenal retroperitoneal paraganglioma: clinical, pathologic, and CT findings. AJR Am J Roentgenol 1990;155(6):1247-50.

9. Timmers HJ, Kozupa A, Chen CC, Carrasquillo JA, Ling $A$, Eisenhofer G, et al. Superiority of fluorodeoxyglucose positron emission tomography to other functional imaging techniques in the evaluation of metastatic SDHB-associated pheochromocytoma and paraganglioma. J Clin Oncol 2007;25(16):22629.
10. Musholt TJ, Weber MM, Fottner C, Helisch A, Schreckenberger M, Musholt PB. Hereditary paraganglioma syndrome PGL-1: diagnostic procedures for localisation of multifocal tumors and surgical strategy in an affected family. Exp Clin Endocrinol Diabetes 2005;113-86. DOI: 10.1055/ s-2005-862945

11. Carney JA, Stratakis CA, Young WF Jr. Adrenal cortical adenoma: the fourth component of the Carney triad and an association with subclinical Cushing syndrome. Am J Surg Pathol 2013;37(8): 1140-9.

12. Thompson LD. Pheochromocytoma of the Adrenal gland Scaled Score (PASS) to separate benign from malignant neoplasms: a clinicopathologic and immunophenotypic study of 100 cases. Am J Surg Pathol 2002;26(5):551-66.

13. Andersen KF, Altaf R, Krarup-Hansen A, Kromann-Andersen B, Horn T, Christensen NJ, et al. Malignant pheochromocytomas and paragangliomas - the importance of a multidisciplinary approach. Cancer Treat Rev 2011;37(2):111-9. 